JKEP

Vol 5, No 1, Mei 2020

ISSN: 2354-6042 (Print)

ISSN : 2354-6050 (Online)

\title{
Efektifitas Aplikasi mHealth Terhadap Manajemen Nyeri Kanker Anak Usia Remaja: Literatur Review
}

\author{
Ayuni Rizka Utami, La Ode Abdul Rahman
}

Universitas Indonesia

Email:ayuniutami5@gmail.com

\author{
Artikel history \\ Dikirim, Des $02^{\text {nd }}, 2019$ \\ Ditinjau, April 29 $9^{\text {th }}, 2020$ \\ Diterima, May $6^{\text {th }}, 2020$
}

\begin{abstract}
Pain is one of a problem in children suffering from cancer which affects to the quality of life of children, inhibits the recovery process, inhibits daily activities and result in longterm morbidity. Aim of this literature review is to identify the therapeutic effect of mHealth (Mobile Health) application for pain management of children suffering from cancer. This article is a literature review using several online databased such as: ClinicalKey, PubMed, Science Direct, ProQuest, EBSCO, Scopus, BioMed Central, and Google Scholar published from 2014-2019 using several of keywords. A selection of 10 full text articles was selected which was then analyzed. The analysis results of 10 articles about mHealth (Mobile Health) therapy in pain management in children suffering from cancer are effective, especially in the management of pain at home. Based on these results, the authors suggest to use mHealth (Mobile Health) therapy in children with cancer to support programmed therapy.
\end{abstract}

Keywords: Cancer, children, mHealth, Pain Management,.

\begin{abstract}
ABSTRAK
Nyeri merupakan salah satu yang selalu menjadi masalah pada anak yang menderita kanker yang mana berdampak terhadap kualitas hidup anak, menghambat proses pemulihan, menghambat aktivitas sehari-hari hingga memperpanjang angka kesakitan. Tujuan dari telaah literatur ini adalah untuk mengidentifikasi manfaat terapi aplikasi mHealth (Mobile Health) terhadap manajemen nyeri anak yang menderita kanker. Artikel ini merupakan literature review dengan menggunakan beberapa sumber elektronik seperti: ClinicalKey, PubMed, Science Direct, ProQuest, EBSCO, Scopus, BioMed Central, dan Google Scholar terbit dari tahun 2014-2019, responden dalam penelitian adalah anak remaja dengan menggunakan beberapa macam kata kunci. Dilakukan pemilihan 8 artikel full text yang kemudian dianalisis. Hasil analisis 8 artikel tersebut adalah terapi mHealth (Mobile Health) efektif dalam majemen nyeri pada anak yang menderita kanker terutama dalam penanganan nyeri di rumah. Berdasarkan hasil tersebut maka penulis menyarankan untuk menerapkan dan melakukan sosialisasi terkait terapi mHealth (Mobile Health) pada anak yang menderita kanker untuk mendukung terapi yang sudah diprogramkan.
\end{abstract}

Kata kunci: Anak, Kanker, Manajemen, mHealth, Nyeri,. 


\section{PENDAHULUAN}

Nyeri merupakan salah satu gejala yang paling sering terjadi pada anak dengan kanker, terutama anak-anak yang mendapatkan kemoterapi. Berdasarkan penelitian yang dilakukan oleh Jibb, L.S (2014) diperkirakan sebanyak 49-62\% anak merasa sakit terkait dengan penyakit atau prosedur perawatan invasif. Nyeri pada anak dengan kanker sebagian besar masuk dalam kategori nyeri kronik karena rata-rata anak dengan kanker merasakan nyeri lebih dari 3 bulan, baik nyeri yang terus menerus maupun nyeri yang terjadi berulang (Voerman, J. S, 2015).

Nyeri memberikan dampak yang negatif terhadap kualitas hidup, menghambat proses penyembuhan, menghambat aktivitas sehari-hari, memperpanjang angka kesakitan dan menimbulkan distress pada anak dan orang tua (Jibb, L. A, 2018). Selain itu nyeri juga merupakan alasan yang paling sering dirasakan oleh anak dengan kanker pada pelayanan gawat darurat yang berdampak terhadap peningkatan pengeluaran (cost) (Jibb, L. A, 2014).

Untuk mengurangi beberapa dampak diatas, ada beberapa hal yang dapat dilakukan oleh anak dan orang tua salah satunya adalah dengan terapi mHealth (Mobile Health). mHealth merupakan strategi intervensi berbasis aplikasi yang digunakan untuk menejemen nyeri kronik pada individu (Tonya M. Palermoa, 2016).

Ada beberapa hal yang terdapat dalam mHealth yaitu terkait dengan edukasi mengenai nyeri, intensitas nyeri, interpretasi nyeri sampai dengan manejemen nyeri secara mandiri serta dukungan social. Adapun terapi tersebut dalam bentuk gambar dan video sehingga mudah untuk diaplikasikan oleh anak dan memebrikan dampak positif bagi peningkatan kualitas hidup anak remaja dengan kanker (Jibb, L. A, 2018).

Di Indonesia belum banyaknya terapi yang memanfaatkan mHeath terutama dengan tujuan untuk manajemen nyeri anak dengan kanker, sedangkan seperti yang kita ketahui bahwa di Indonesia sendiri hampir semua kalangan menggunakan ponsel pintar yang dapat mengakses berbagai aplikasi mHealth sehingga hal ini dapat dimanfaatkan untuk memberikan menejemen terapi nyeri melalui ponsel pada anak remaja. Dengan berkembangnya teknoloi sat ini, smart phone merupkan salah satu benda wajib yang dimiliki oleh seseorang dan mampu memudahkan hampir semua aspek kehidupan. Dengan banyaknya masyarkat yang memiliki smart phone saat ini menandakan bahwa harganya dapat dijangkau oleh masyarakat 
luas sehingga dapat dikatakan bahwa terapi dengan mHealth sangat mungkin untuk dilakukan terutama jika dilihat dari segi ekonomi dan keterjangkauan untuk mendapatkan aplikasi (Richards, R,2018). Tujuan dari telaah literatur ini adalah untuk mengidentifikasi manfaat terapi aplikasi mHealth (Mobile Health) terhadap manajemen nyeri anak remaja yang menderita kanker.

\section{METODE}

Metode dari penelitian ini menggunakan kajian literatur Bahasa inggris atau systematic literature review yang relevan

\section{HASIL DAN PEMBAHASAN}

Hasil analisis dari 8 artikel yang sesuai dengan topik menunjukkan bahwa aplikasi mHealth sudah banyak dilakukan namun dalam bentuk aplikasi yang berbeda-beda dan jenis edukasi serta terapi yang berbeda dengan topik yang diangkat melalui pencarian elektronik data based ClinicalKey, PubMed, Science Direct, ProQuest, EBSCO, Scopus, BioMed Central, dan Google Scholar. Terbit dari tahun 2014-2019 dengan kata kunci "(mHealth OR Mobile Health) and (Cancer Pain) and (Pediatric OR Children OR Adolescents). Setelah dilakukan penyaringan, didapatkan 8 artikel yang sesuai dengan topik yang diangkat dengan kriteria inklusi terbit dari tahun 2014-2019, responden dalam penelitian adalah anak sampai usia remaja dan full text.

pula. Pada tabel 1.1 menjelaskan bahwa semua literatur menyatakan mHealth sangat efektif untuk digunakan dalam manejemen nyeri anak dengan kanker.

Tabel.1.1 (Terapi mHealth pada nyeri anak dengan kanker)

\begin{tabular}{|c|c|c|c|c|c|c|c|}
\hline No & Penulis & $\begin{array}{c}\text { Nama } \\
\text { Aplikasi }\end{array}$ & Sampel & $\begin{array}{c}\text { Jenis } \\
\text { Penelitian }\end{array}$ & Lokasi & $\begin{array}{c}\text { Tujuan } \\
\text { Penelitian }\end{array}$ & Hasil \\
\hline 1 & $\begin{array}{l}\text { Ryan } \\
\text { Nussbaum, } \\
\text { DO, } \\
\text { Christopher } \\
\text { Kelly, BS, } \\
\text { Eleanor } \\
\text { Quinby, BS, } \\
\text { Ami Mac, MD, } \\
\text { Bambang } \\
\text { Parmanto, } \\
\text { PhD,Brad E. } \\
\text { Dicianno, MD } \\
\text { (2019) }\end{array}$ & mHealth & $\begin{array}{c}102 \text { full } \\
\text { text }\end{array}$ & $\begin{array}{l}\text { Systematic } \\
\text { Reviews } \\
\text { dengan } \\
\text { Meta- } \\
\text { Analysis }\end{array}$ & $\begin{array}{l}\text { Pennsylv } \\
\text { ania }\end{array}$ & $\begin{array}{l}\text { Melakukan } \\
\text { sistematik } \\
\text { review sejauh } \\
\text { mana aplikasi } \\
\text { digunakan } \\
\text { dengan } \\
\text { dukungan } \\
\text { pengobatan fisik } \\
\text { dan rehabilitatif }\end{array}$ & $\begin{array}{l}\text { Aplikasi dari } \\
\text { mHealth } \\
\text { memberikan } \\
\text { dampak yang } \\
\text { positif } \\
\text { terhadap } \\
\text { rehabilitasi } \\
\text { pasien salah } \\
\text { satunya adalah } \\
\text { nyeri }\end{array}$ \\
\hline 2 & $\begin{array}{l}\text { Michelle A. } \\
\text { Fortier, Winnie } \\
\text { W. Chung, }\end{array}$ & $\begin{array}{l}\text { Pain } \\
\text { Buddy }\end{array}$ & $\begin{array}{l}12 \text { anak } \\
\text { usia } 8- \\
18\end{array}$ & Experiment & $\begin{array}{c}\text { Californi } \\
\text { a, USA }\end{array}$ & $\begin{array}{l}\text { Menganalisis } \\
\text { efektifitas } \\
\text { aplikasi untuk }\end{array}$ & $\begin{array}{l}\text { mHealth } \\
\text { dalam bentuk } \\
\text { Pain Buddy }\end{array}$ \\
\hline
\end{tabular}




\begin{tabular}{|c|c|c|c|c|c|c|c|}
\hline No & $\begin{array}{l}\quad \text { Penulis } \\
\text { Ariana } \\
\text { Martinez } \\
\text { Sergio Gago- } \\
\text { Masague, } \\
\text { Leonard } \\
\text { Sender (2016) }\end{array}$ & $\begin{array}{c}\text { Nama } \\
\text { Aplikasi }\end{array}$ & $\begin{array}{l}\text { Sampel } \\
\text { tahun }\end{array}$ & $\begin{array}{c}\text { Jenis } \\
\text { Penelitian }\end{array}$ & Lokasi & \begin{tabular}{l}
\multicolumn{1}{c}{ Tujuan } \\
\multicolumn{1}{c}{ Penelitian } \\
manajemen nyeri \\
dan peningkatan \\
kualitas hidup \\
pada anak yang \\
sedang \\
melakukan \\
pengobatan \\
kanker
\end{tabular} & \begin{tabular}{l}
\multicolumn{1}{c}{ Hasil } \\
sebagai alat \\
yang inovatif \\
dan interaktif \\
dapat \\
menurunkan \\
tingkat nyeri \\
dan dapat \\
digunakan \\
sebagai \\
manajemen \\
nyeri pada \\
anak
\end{tabular} \\
\hline 3 & $\begin{array}{l}\text { Winnie W. } \\
\text { Chung, } \\
\text { Crystle-Joie G. } \\
\text { Agbayani, } \\
\text { Ariana } \\
\text { Martine, Vu } \\
\text { Le, Haydee } \\
\text { Cortes, Kim } \\
\text { Har, Zeev N. } \\
\text { Kain, Michelle } \\
\text { A. Fortier } \\
\text { (2018) }\end{array}$ & $\begin{array}{l}\text { Cancer- } \\
\text { Tailored } \\
\text { Interventi } \\
\text { on for } \\
\text { Pain and } \\
\text { Symptoms } \\
\text { (C-TIPS) }\end{array}$ & $\begin{array}{l}30 \text { anak } \\
\text { usia 3- } \\
17 \\
\text { tahun }\end{array}$ & Experiment & USA & $\begin{array}{l}\text { Mengevaluasi } \\
\text { efektifitas } \\
\text { aplikasi C-TIPS } \\
\text { berbasis web } \\
\text { terhadap nyeri } \\
\text { anak yang } \\
\text { mengalami } \\
\text { kanker dan } \\
\text { mendapatkan } \\
\text { perawatan di } \\
\text { rumah }\end{array}$ & $\begin{array}{l}C \text {-TIPS } \\
\text { merupakan } \\
\text { intervensi } \\
\text { yang layak } \\
\text { untuk diterima } \\
\text { dan digunakan } \\
\text { karena dapat } \\
\text { meningkatkan } \\
\text { kualitas hidup } \\
\text { anak dan } \\
\text { orang tua } \\
\text { dengan kanker }\end{array}$ \\
\hline 4 & $\begin{array}{l}\text { Jessica S. } \\
\text { Voerman,Sylvi } \\
\text { a } \\
\text { Remerie,Tessa } \\
\text { Westendorp,Re } \\
\text { inier } \\
\text { Timman,Jan J. } \\
\text { V. } \\
\text { Busschbach,Ja } \\
\text { n Passchier,and } \\
\text { Cora de Klerk } \\
\text { (2015) }\end{array}$ & $\begin{array}{l}\text { Move It } \\
\text { Now } \\
\text { interactiv } \\
\text { e CBT } \\
\text { Internet } \\
\text { interventi } \\
\text { on }\end{array}$ & $\begin{array}{l}69 \text { anak } \\
\text { usia } \\
12-17 \\
\text { tahun }\end{array}$ & Experiment & $\begin{array}{l}\text { Amsterd } \\
\text { am, } \\
\text { Netherla } \\
\text { nds. }\end{array}$ & $\begin{array}{l}\text { Mengevaluasi } \\
\text { efektifitas } \\
\text { penanganan } \\
\text { nyeri berbasis } \\
\text { internet terhadap } \\
\text { nyeri kronis } \\
\text { remaja }\end{array}$ & $\begin{array}{l}\text { Move it Now } \\
\text { dengan } \\
\text { Interaktif } \\
\text { intervensi } \\
\text { berbasis } C B T \\
\text { dapat } \\
\text { mengurangi } \\
\text { rasa nyeri } \\
\text { kronis pada } \\
\text { anak dengan } \\
\text { intervensi } \\
\text { mandiri }\end{array}$ \\
\hline 5 & $\begin{array}{l}\text { Tonya M. } \\
\text { Palermo, Rocio } \\
\text { de la Vega, } \\
\text { Joanne } \\
\text { Dudeney, } \\
\text { Caitlin Murray, } \\
\text { Emily Law } \\
\text { (2018) }\end{array}$ & $\begin{array}{l}\text { WebMAP } \\
\text { Mobile }\end{array}$ & $\begin{array}{l}120 \\
\text { anak } \\
\text { usia } \\
10-17 \\
\text { tahun }\end{array}$ & Experiment & USA & $\begin{array}{l}\text { Menganalisis } \\
\text { efektifitas } \\
\text { manajemen nyeri } \\
\text { secara mandiri } \\
\text { berbasis web } \\
\text { mobile }\end{array}$ & $\begin{array}{l}\text { Berdasarkan } \\
\text { hasil uji coba } \\
\text { WebMAP } \\
\text { Mobile } \\
\text { merupakan } \\
\text { pendekatan } \\
\text { yang inovatif } \\
\text { untuk program } \\
\text { dan evaluasi } \\
\text { nyeri kronis } \\
\text { pada anak }\end{array}$ \\
\hline 6 & $\begin{array}{l}\text { Lindsay A } \\
\text { Jibb, RN, MSc; } \\
\text { Bonnie J }\end{array}$ & $\begin{array}{l}\text { Smartpho } \\
\text { ne-Based } \\
\text { Pain }\end{array}$ & $\begin{array}{l}15 \text { full } \\
\text { text }\end{array}$ & $\begin{array}{l}\text { Systematic } \\
\text { review }\end{array}$ & Canada & $\begin{array}{l}\text { Mengembangka } \\
\mathrm{n} \text { keputusan } \\
\text { algoritma dan }\end{array}$ & $\begin{array}{l}\text { Smartphone- } \\
\text { Based Pain } \\
\text { Management }\end{array}$ \\
\hline
\end{tabular}




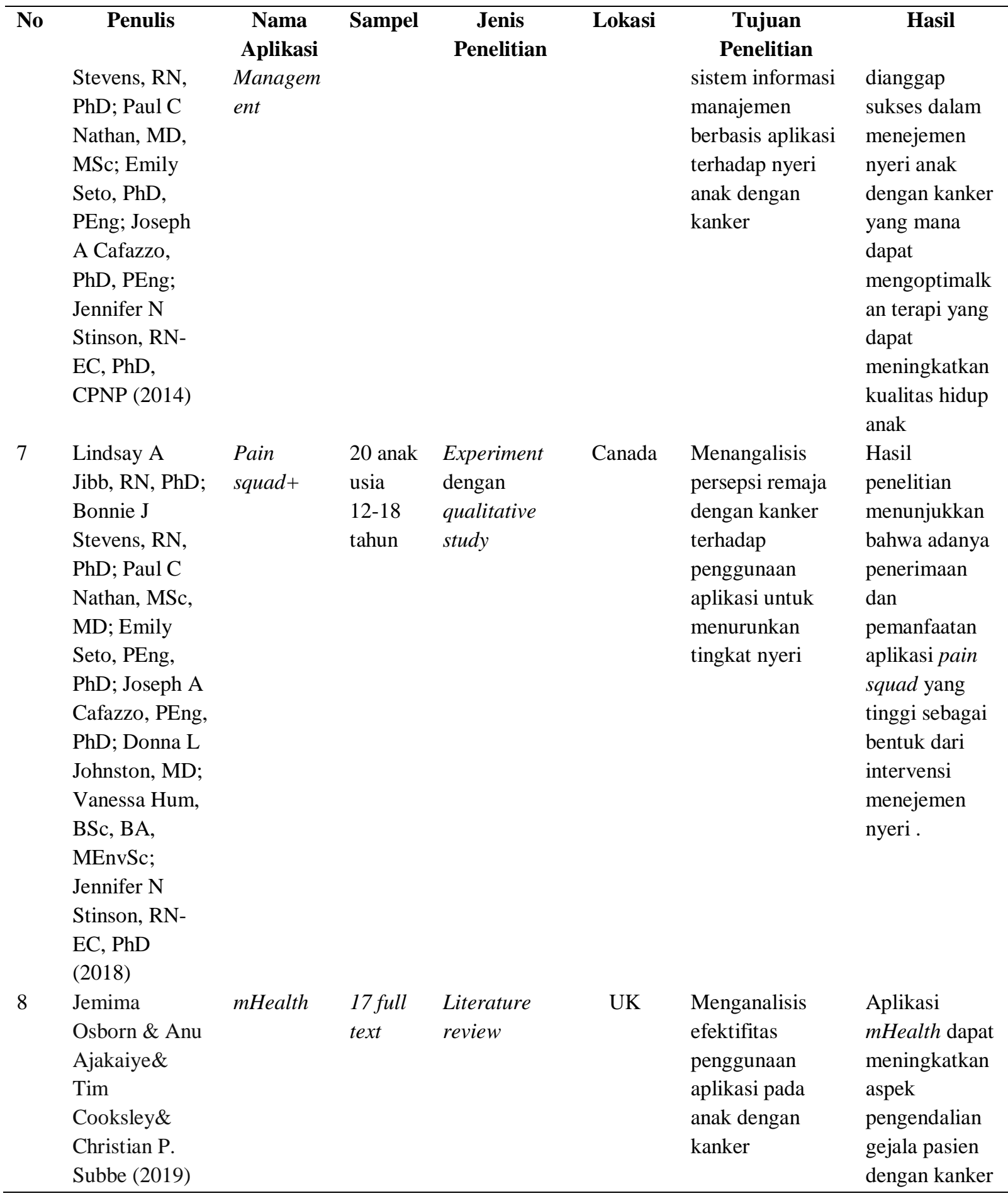

mHealth merupakan intervensi layanan kesehatan yang digunakan dengan tujuan untuk meningkatkan pelayanan kesehatan, tujuan dari mHealth adalah untuk memberikan layanan kesehatan terutama pada negara-negara berkembang dimana mobile seluler memiliki penetrasi yang tinggi (Beratarrechea, 2017). mHealth merupakan mobile device seperti ponsel, perangkat pemantau pasien, asisten pribadi dan perangkat nirkabel untuk praktik medis dan kesehatan masyarakat (Bakırc1-Taylor, A, 2019). Mobile health apps juga merupakan 
sumber layanan dengan biaya rendah namun efektif dalam memberikan layanan kesehatan (Nussbaum, R, 2019).

Kemajuan teknologi dalam kesehatan berupa mHealth dapat mengurangi hambatan untuk mendapatkan akses layanan dalam intervensi perilaku nyeri, berdasarkan beberapa studi menyebutkan bahwa mHealth mampu mengelola penyakit kronis seperti kanker dan aplikasi tersebut layak digunakan, dapat diterima dan memeberikan efek yang positif (Somers, T. J, 2015).

Jenis dari mHealth sangat bermacammacam seperti yang sudah digambarkan pada table 1.1 yang mana masing-masing memiliki komponen yang berbeda-beda namun dengan tujuan yang sama yaitu melakukan manajemen nyeri untuk meningatkan kulitas hidup anak dengan kanker. Berdasarkan telaah literatur diatas ada beberapa yang menjadi fokus edukasi dan intervensi yaitu pengontrolan nyeri, pengontrolan nyeri ketika aktivitas, kontrol nyeri ketika tidur dan mengurangi nyeri tanpa medikasi tambahan. Adapun jenis mHealth lainnya fokus pada edukasi intervensi nyeri dengan cara relaksasi otot progresif, guided imagery, pernafasan diafragma serta distraksi. Pada penelitian yang lainnya juga disebutkan bahwa intervensi yang dimasukkan dalam aplikasi tidak hanya berupa menejemen nyeri namun terkait fungsi fisik, fungsi emosional, upaya dalam melakukan aktivitas sehari-hari, nyeri tubuh, kebiasaan secara keseluruhan, kesehatan mental, persepsi diri, perubahan dalam kesehatan sampai dengan aktivitas keluarga. Sehingga dapat dikatakan bahwa penggunaan mHealth akan memberikan dampak yang holistic kepada pasien.

Penelitian sebagaian besar dilakukan pada anak remaja dengan rata-rata rentang usia 8-18 tahun, ini dikarenakan pada intervensi dengan mHealth sebagian besar menggunakan cognitive-behavioral therapy (CBT) yang mana anak dengan usia adolescent atau anak remaja mampu melakukan aktivitas tersebut dan dapat dilakukan secara mandiri. Sehingga harapannya setelah dilakukan intervensi dalam waktu tertentu anak tersebut mampu untuk melakukan manajemen nyeri secara mandiri karena sudah sesuai dengan kemampuan kognitif yang dimiliki. Namun ada penelitian yang menggunakan sampel dengan usia 3-17 tahun dikarenakan adanya pelibatan orang tua dalam intervensi tersebut sehingga diharapkan orang tua dalam membantu keberlangsungan intervensi (Osborn, 2019) 


\section{SIMPULAN}

Berdasarkan analisis artikel yang telah dilakukan maka dapat disimpulkan bahwa mHealth merupakan aplikasi yang sangat efektif dan efisien untuk digunakan dengan bentuk aplikasi yang beragam mencakup berbagai intervensi kesehatan terutama edukasi dan manajemen nyeri pada dengan tujuan untuk peningkatan pelayanan kesehatan, sehingga dapat dikatakan bahwa mHealth memiliki manfaat yang positif terhadap nyeri dan peningkatan kualitas hidup anak dengan kanker.

Berdasarkan telaah jurnal ini penulis merekomendasikan untuk menggunakan aplikasi mHealth dengan jenis yang sesuai dengan kebutuhan anak untuk manejemen nyeri kanker sehingga dapat meningkatkan kuliatas hidup pada anak dengan kanker. Dengan intervensi nyeri melalui aplikasi tersebut diharapkan terjadi kesinambungan antara intervensi nyeri non farmakologi yang diberikan oleh perawat pada saat hospitalisasi sehingga ketika di rumah anak mampu untuk melakukan manajemen nyeri mandiri yang berdampak terhadap peningkatan kualitas hidup anak. Aplikasi tersebut juga dapat membantu perawat untuk melakukan rekam jejak kondisi kesehatan pasien terkait nyeri selama perawatan di rumah, sehingga tidak terputusnya pemantauan perkembangan anak dengan kanker dalam upaya peningkatan kualitas hidup. Adapun rekomendasi bagi peneliti selanjutnya adalah mengidentifikasi jenis aplikais mana yang dikatakan lebih efektif untuk menurunkan nyeri dan meningkatkan kualitas hidup anak dengan kanker.

\section{UCAPAN TERIMA KASIH}

Terima kasih kepada semua pihak yang telah memberikan peran dan kontribusinya dalam penelitian ini.

\section{DAFTAR RUJUKAN}

Basch, E., Deal, A. M., Kris, M. G., Scher, H. I., Hudis, C. A., Sabbatini, P., ... Schrag, D. (2016). Symptom monitoring with patient-reported outcomes during routine cancer treatment: A randomized controlled trial. Journal of Clinical Oncology, 34(6), 557-565. https://doi.org/10.1200/JCO.2015.63. $\underline{0830}$

Beratarrechea, A., Moyano, D., Irazola, V., \& Rubinstein, A. (2017). mHealth Interventions to Counter Noncommunicable Diseases in Developing Countries: Still an Uncertain Promise. Cardiology Clinics, 35(1), 13-30. https://doi.org/10.1016/j.ccl.2016.08. $\underline{009}$

Bakırc1-Taylor, A. L., Reed, D. B., McCool, B., \& Dawson, J. A. (2019). mHealth Improved Fruit and Vegetable Accessibility and Intake in Young Children. Journal of Nutrition Education and Behavior, 51(5), 556566. https://doi.org/10.1016/j.jneb.2018.11 .008 
Chung, W. W., Agbayani, C. J. G., Martinez, A., Le, V., Cortes, H., Har, K., ... Fortier, M. A. (2018). Improving Children's cancer pain management in the home setting: Development and formative evaluation of a web-based program for parents. Computers in Biology and Medicine, 101(May 2018), 146152.https://doi.org/10.1016/j.compbio med.2018.08.014

Fortier, M. A., Chung, W. W., Martinez, A., Gago-Masague, S., \& Sender, L. (2016). Pain buddy: A novel use of m-health in the management of children's cancer pain. Computers in Biology and Medicine, 76, 202-214. https://doi.org/http://dx.doi.org/10.10 16/j.compbiomed.2016.07.012

Jibb, L. A., Cafazzo, J. A., Nathan, P. C., Seto, E., Stevens, B. J., Nguyen, C., \& Stinson, J. N. (2017). Development of a mHealth Real-Time Pain SelfManagement App for Adolescents With Cancer: An Iterative Usability Testing Study. Journal of Pediatric Oncology Nursing, 34(4), 283-294. https://doi.org/10.1177/10434542176 $\underline{97022}$

Jibb, L. A., Stevens, B. J., Nathan, P. C., Seto, E., Cafazzo, J. A., Johnston, D. L., ... Stinson, J. N. (2018). Perceptions of adolescents with cancer related to a pain management app and its evaluation: Qualitative study nested within a multicenter pilot feasibility study. JMIR MHealth and UHealth, 6(4). https://doi.org/10.2196/mhealth.9319
Jibb, L. A., Stevens, B. J., Nathan, P. C., Seto, E., Cafazzo, J. A., \& Stinson, J. N. (2014). A smartphone-based pain management app for adolescents with cancer: Establishing system requirements and a pain care algorithm based on literature review, interviews, and consensus. Journal of Medical Internet Research, 16(3), 113.

https://doi.org/10.2196/resprot.3041

Lalloo, C., Hundert, A., Harris, L., Pham, Q., Campbell, F., Chorney, J., ... Stinson, J. (2019). Capturing daily disease experiences of adolescents with chronic pain: MHealth-mediated symptom tracking. Journal of Medical Internet Research, 21(1), 113. https://doi.org/10.2196/11838

Nussbaum, R., Kelly, C., Quinby, E., Mac, A., Parmanto, B., \& Dicianno, B. E. (2019). Systematic Review of Mobile Health Applications in Rehabilitation. Archives of Physical Medicine and Rehabilitation, 100(1), 115-127. https://doi.org/10.1016/j.apmr.2018.0 $\underline{7.439}$

Osborn, J., Ajakaiye, A., Cooksley, T., \& Subbe, C. P. (2019). Do mHealth applications improve clinical outcomes of patients with cancer? A critical appraisal of the peer-reviewed literature. Supportive Care in Cancer. https://doi.org/10.1007/s00520-01904945-4 
Palermo, T. M., de la Vega, R., Dudeney, J., Murray, C., \& Law, E. (2018). Mobile health intervention for selfmanagement of adolescent chronic pain (WebMAP mobile): Protocol for a hybrid effectivenessimplementation cluster randomized controlled trial. Contemporary Clinical Trials, 74(May 2018), 5560.https://doi.org/10.1016/j.cct.2018. 10.003

Palermo, T. M., Zempsky, W. T., Dampier, C. D., Lalloo, C., Hundert, A. S., Murphy, L. K., ... Stinson, J. N. (2018). iCanCope with Sickle Cell Pain: Design of a randomized controlled trial of a smartphone and web-based pain self-management program for youth with sickle cell disease. Contemporary Clinical Trials, 74(October 2018), 88-96. https://doi.org/10.1016/j.cct.2018.10. $\underline{006}$

Richards, R., Kinnersley, P., Brain, K., McCutchan, G., Staffurth, J., \& Wood, F. (2018). Use of mobile devices to help cancer patients meet their information needs in noninpatient settings: Systematic review. JMIR MHealth and UHealth, 6(12). https://doi.org/10.2196/10026
Somers, T. J., Abernethy, A. P., Edmond, S. N., Kelleher, S. A., Wren, A. A., Samsa, G. P., \& Keefe, F. J. (2015). A Pilot Study of a Mobile Health Pain Coping Skills Training Protocol for Patients with Persistent Cancer Pain. Journal of Pain and Symptom Management, 50(4), 553-558. https://doi.org/10.1016/j.jpainsymma $\underline{\text { n.2015.04.013 }}$

Tonya M. Palermoa, b, ${ }^{*}$, Emily F. Lawa, b, Jessica Falesc, Maggie $H$. Brombergb, Tricia Jessen- Fiddickb, and G. T. (n.d.). nihms722316.pdf (p. 2016). p. 2016.

Voerman, J. S., Remerie, S., Westendorp, T., Timman, R., Busschbach, J. J. V., Passchier, J., \& De Klerk, C. (2015). Effects of a Guided InternetDelivered Self-Help Intervention for Adolescents with Chronic Pain. Journal of Pain, 16(11), 1115-1126. https://doi.org/10.1016/j.jpain.2015.0 7.011 